\title{
THE RELATION BETWEEN THE STERILITY EQUIPMENTS IN INFUSION TIME INSTITUTION AND FLOODBURY PRESENTATION IN FLAMBOYAN HOSPITAL ABDUL WAHAB SJAHRANIE SAMARINDA
}

\author{
Alfi Ari Fakhrur Rizal ${ }^{1}$ \\ ${ }^{1}$ D3 Nursing Study Program. Faculty of Health and Pharmacy, Universitas Muhammadiyah \\ Kalimantan Timur, Indonesia \\ Aafr597@umkt.ac.id
}

\begin{abstract}
The nurse plays a significant role in caring for and helping someone from illness, wound. Hospital nursing service is a part that cannot be separated from health care as a whole, even as one factor determinant ao quality for service and image of the hospital in the eyes of society. To identify the relation between sterility of equipment on-time installation of in infusion with plaque incidence in the flamboyant space of disease in RSUD A.W SjahranieSamarinda Year 2016, This research uses descriptive correlative research design that is A research method undertaken to create descriptions or descriptions come to the situation that is being or done objectively, with a cross-sectional approach. According to SPO, the patient with happened phlebitis as much as one patient (25\%), and accordingly, SPO did not occur phlebitis as many as seven patients (64\%). While those that do not fit the SPO phlebitis occurred as many as three patients $(75 \%)$ and no SPO did not occur phlebitis as many as 4patients (36\%). That according to SPO, there was one patient phlebitis (25\%), and accordingly soup There was no phlebitis of 7 patients (64\%). While non-conforming SPO occurs phlebitis as much as three patients $(75 \%)$ and no SPO did not occur phlebitis as many as four patients $(36 \%)$. The results of this study found that.
\end{abstract}

Keywords: Sterility Equipments, Infusion, Phlebitis, Nursing, Health Care

\section{INTRODUCTION}

Services in hospitals are multi-disciplinary services; one of the health services contributing to determine the quality and shaping the image of the hospital is nurses. Nursing services in hospitals are inseparable parts of overall health services, even as one of the determinants of quality for hospital services and image in the eyes of the public. Nursing services follow the development of science and technology in the health care system; one of the strategies taken is to maintain the quality of human resources (nurse competence). Nurse competencies, such as duties and authority, need to be understood. Nurses are always required to be able to perform all forms of nursing actions based on the knowledge gained, including invasive actions such as the installation of intravenous therapy (infusion).

Intravenous therapy is one of the main therapies used to treat various patient conditions in all treatment environments in the hospital. Intravenous therapy is useful to correct or prevent fluid and electrolyte imbalances in the human body. Peripheral intravenous therapy is needed to provide fluid therapy to acute or chronic ill clients ${ }^{1}$. This therapeutic system has a direct effect, is faster, more effective, can be carried out continuously and sufferers feel more comfortable whencompared with other methods. Infusion that performed 
in a hospital is an invasive procedure. However, this is a high risk of infection that will increase the high cost of treatment as well as the time. The infusion installation will be of quality if in its implementation always refers to the standards set. As many as $70 \%$ of patients hospitalized get intravenous fluid therapy. But because this therapy is given continuously and in the long term will certainly increase the possibility of complications from infusion, one of which is an infection ${ }^{2}$.

One infection that often found in hospitals is a nosocomial infection. Nosocomial infections caused by diagnostic procedures that often arise is phlebitis. The success of controlling nosocomial infections in infusion is not determined by the sophistication of existing equipment but is determined by the behaviour of officers in carrying out client care properly ${ }^{3}$. Phlebitis is defined as inflammation of the walls of the veins or veins ${ }^{4}$. Phlebitis is a venous inflammation caused by both chemical and mechanical irritation that is often caused by complications from intravenous therapy. Phlebitis is characterized by the presence of two or more signs of pain, redness, swelling, induration, and palpable hardening in the venous region that is attached by an intravenous cathete . $^{5}$

Phlebitis simply means inflammation of the veins. Severe phlebitis is almost always followed by a blood clot or thrombus in the diseased vein. Phlebitis can cause thrombus which subsequently becomes thrombophlebitis, the course of this disease is usually benign, but even so, if the thrombus is released then transported in the bloodstream and into the heart it can cause blood clots like ball valves which can clog sudden atrioventricular and cause death $^{6}$.

Research conducted at RS. Sarjito Yogyakarta in 2002 found 27.19\% of cases of phlebitis after infusion. Found as many as $18.8 \%$ cases of phlebitis in Purworejo District Hospital in 2003. And in the inpatient hospital, DrSoeradjiTirtonegoroKlaten in 2002 found phlebitis as much as $26.5 \%$ of cases.

On the research conducted shows that nurses paid less attention to the sterility of the wound during infusion. Nurses usually immediately put the infusion without measuring the availability of materials needed in the procedure; the hands-on is not available, sterile gauze, alcohol, repeated use in an unsterile infusion tube ${ }^{3}$.

The results of researchwhich conducted a study entitled Review of Implementation of Standard Operating Procedure (SOP) for Infusion Installation in Patients in Emergency Room Installation of PKU MuhammadiyahGombong Hospital showed nurses tended not to adhere to the preparation of Equipments and procedures for principle infusion. The results of the study of 12 nurses who carried out the injection, nurses who were not compliant as many as 12 people or $100 \%$ and as many as 0 or $0 \%$ compliant $^{6}$.

The resultswhich conducted an analysis of the implementation of infusion in the inpatient ward of Medan Haji Hospital showed that the implementation of infusion in accordance with the Standard Operating Procedures in the category of good 27\%, 40\% moderate and $33 \%$ bad. The number of occurrences of phlebitis according to the distribution of blood circulation system diseases inpatients, Indonesia in 2010 amounted to 744 people $(17.11 \%)^{7}$. Based on data from the medical record that the incidence of phlebitis in general in patients receiving intravenous therapy in the inpatient room in the RSUD A.W SjahranieSamarinda in 2014 was 13.83\%, an increase compared to 2013 which was $8.437 \%$. From these data indicate that patients are still encountered after infusion of phlebitis. This shows that the percentage of patients with local infections, namely phlebitis, is still quite 
large because it is still above the standard recommended by the INS (Intravenous Nurses Society), which is $5 \%$.

The results of observations made by researchers in the Internal Medicine Flamboyant Room A.W Sjahranie Hospital Samarinda, found nurses who carry out infusion installation procedures are not in accordance with fixed procedures. Based on interviews with tenten nurses in the room, found $8(80 \%)$ nurses who did not do the SOP in the installation of infusion. This is indicated by nurses who do not wash their hands first, do not use handsets, do not use tourniquet, do not use crooked and alcohol cotton that has been used is placed in the same place with clean equipment. The nurse believes that infusion is a common thing to do. Even when asked about the issue of the procedure for inserting IVs, they knew little about the contents of the procedure, and when it was observed while carrying out IVs, it turned out that there were several criteria that were not implemented in accordance with the contents of the procedure, especially the problem of washing hands.

\section{MATERIAL AND METHOD}

This study uses a correlative descriptive research design that is a research method carried out to create a picture or description of a situation that is being or carried out objectivel, with a cross sectional approach. The cross sectional approach is a study conducted to describe the relation between independent variables and dependent variables, together in a certain period $^{8}$. Data obtained from observation sheets given to nurses in the flamboyant room. Data were then analyzed for the relation between the sterility of the device and the incidence of plebitis in the flamboyant room of Abdul WahabSjahranie Hospital Samarinda.

Population In this study, the research population was all nurses in the flamboyant room of Abdul WahabSjahranieHospital Samarinda. With a total population of 28 people and the sample in this study using Accidental Sampling and this study the number of existing research samples is 15 respondents. The place that will be used as research land is the Flamboyant Room Abdul WahabSjahranie Hospital Samarinda.

In this study, what will be done univariate analysis are age, sex, education, length of work, compliance and incidence of plebitis. While the bivariate analysis in this study is the relation between the sterility of the device at the time of infusion installation and the incidence of plebitis using the Chi Square statistical test formula with significance level $\alpha=$ 0.05

\section{RESULTS AND DISCUSSION}

\section{A.Result}

\section{Analysis of Characteristics of Respondents}

a. Characteristics, Respondents by Gender

Tabel 1 DistribusiRespondenBerdasarkanJenisKelamin Di RuangFlamboyanRumahSakitUmum Daerah Abdul WahabSjahranieSamarinda

\begin{tabular}{|c|c|c|}
\hline Gender & Frequency & $(\%)$ \\
\hline Female & 13 & 86,6 \\
\hline Male & 2 & 13,3 \\
\hline Total & 15 & 100 \\
\hline
\end{tabular}

Source: Primary Data for 2017 
Based on gender in this study it was found that respondents who were female were $13(86.6 \%)$ while male respondents were $2(13.3 \%)$.

Where the distribution of respondents in this study there are more female respondents than male respondents. This is because the ratio of the number of female nurses is more than male nurses, besides male nurses are more placed in the emergency room and operating room this is because in the room many patients whose conditions are needed male nurses to anticipate it.

This is consistent with the history of the development of nursing with the struggle of Florence Nightingale so that the world of nursing is identical to the work of a woman. However, this condition has now changed, many men become nurses, but in reality the proportion of women is still more than men.

This is in accordance with the opinion expressed stating that the world of nursing is very dominated by women, because of their interest as well as most women compared to men, other than that the nursing profession is considered synonymous with a motherhood woman. Female nurses, in general, have advantages compared to male nurses which lie in patience, accuracy, responsiveness, tenderness, instincts to educate, care for, nurture, serve, and guide.

At present the number of female nurses is greater than that of men, this is because each nurse education institution annually produces more female nurses and the work of nurses is very identical to the work of women.

The research assumes that there is no difference between the sexes of men and women with respect to work, but in reality, the occupational profession of nursing is dominated by women. In fact, in Abdul Wahab Hospital SjahranieSamarinda, especially in the Flamboyan room around $86.6 \%$ of nurses, were female and the remaining $13.3 \%$ were male.

\section{b. Characteristics of Respondents by Age}

Table 2 Distribution of Respondents by Age in the Flamboyant Room of Abdul WahabSjahranie Regional Hospital Samarinda

\begin{tabular}{|c|c|c|}
\hline Age & Frequency & $(\%)$ \\
\hline$<30$ years old & 13 & 86,6 \\
\hline > 30 years old & 2 & 13,3 \\
\hline Total & 15 & 100 \\
\hline
\end{tabular}

Source: Primary Data for 2017

Based on the table above, it was found that from 15 respondents it was found that the majority of respondents aged $<30$ years, namely as many as $13(86.6 \%)$ and respondents aged $>$ $30(13.3 \%)$.

Frequency distribution based on age shows that from the 15 respondents involved in this study, some respondents $>30$ years were 13 respondents $(86.6 \%)$ while $\geq 30$ years were 2 respondents $(13.3 \%)$.

According to the Indonesian Ministry of Healththe age category is divided into three categories based on the level of biological maturity that a person has, namely 
adolescents, adults, the elderly. Lomenta also believes that productive age has greater demands and expectations in receiving therapy compared to old age.

For some young adults is the most productive period which is usually at the peak of their careers. This is in line with the opinion of stating that age is one of the characteristics that affect performance ${ }^{9}$.

c. Characteristics of Respondents Based on Education

Distribution of Respondents Distribution Based on Education in the Flamboyant Room Abdul WahabSjahranie Regional Hospital Samarinda

\begin{tabular}{|c|c|c|}
\hline Education & Frequency & $(\%)$ \\
\hline DIII & 12 & 80 \\
\hline S1 & 3 & 20 \\
\hline Total & 15 & 100 \\
\hline
\end{tabular}

Source: Primary Data for 2017

The frequency distribution of respondents based on education shows that from the 15 respondents involved in this study, the majority of DIII education was 12 respondents (80\%) while S1 education was 3 respondents (20\%).

This is in accordance opinion, nurses with a sufficiently good education will practice effective and efficient nursing practices, which in turn will produce high-quality health services. An adequate level of education will contribute to nursing practice. Nurse education affects the performance of nurses because the higher the education is taken, the more knowledge and skills possessed by nurses so that it will be able to help in improving performance in providing nursing care in patients.

In this study, the majority of education data obtained is Nursing DIII, according to the researchers' assumptions this is because there is currently no nursing education school (SPK). So that nurses already have a minimum of DIII Nursing education, in addition, it has begun requiring a nurse to have DIII Nursing education by nursing professional organizations

d. Characteristics, Respondents Based on Length of Work

Table 4 Distribution of Respondents by Length of Work in Flamboyant Room Abdul WahabSjahranie Regional Hospital Samarinda

\begin{tabular}{lcc}
\hline \multicolumn{1}{c}{ Length of working } & Frequency & $(\boldsymbol{\%})$ \\
\hline$<5$ years & 13 & 86,7 \\
5 years & 2 & 13 \\
\hline Total & 15 & 100 \\
\hline
\end{tabular}

Source: Primary Data for 2017

Distribution of respondents' frequency based on length of work shows that of the 15 respondents involved with this study, the majority of the length of work $<5$ years amounted to 10 respondents $(66.6 \%)$ and $>5$ years 5 respondents $(33.3 \%)$. The time someone has gone through since pursuing work. The length of work can illustrate a person's experience in mastering the area of their duties. In general, officers with a lot of work experience do not need guidance compared to officers with little work experience. 
According to the longer a person works in an organization, the more experienced the person will be so that his work skills are bett

\section{UnivariateAnalysis}

a. Variabel Independent( Variabel Independent )

Table 5 Distribution based on the sterility of the device in the installation of infusion in the flamboyant room Abdul WahabSjahranie Hospital Samarinda

\begin{tabular}{lcc}
\hline \multicolumn{1}{c}{ Sterility of equipment } & Frequency & $(\boldsymbol{\%})$ \\
\hline Sterile & 4 & 26,7 \\
unsterilized & 11 & 73,3 \\
\hline Total & 15 & 100 \\
\hline
\end{tabular}

Source: Primary Data

Based on table 5, it can be seen that most respondents according to SPO occurred plebitis in 1 patient (25\%), and according to SPO there was no plebitis in 4 patients (36\%), a process to kill all microorganisms that exist in the equipments if grown in nature in a medium no microorganisms can reproduce that is in the equipments. Sterilization must be able to kill microorganisms so that the equipmentss used are sterile and do not cause instability of the equipments. The growth of microorganisms shows that bacterial growth is still ongoing and the sterilization process is incomplete. If the sterilization is complete, the bacterial spores which are the most resistant form of microbial life will be destroyed. For the purpose of microbiology in an effort to obtain a sterile state, microorganisms can be killed locally by heat (heat), gases such as formaldehyde, ethylene oxide or betapriolactone by various chemical solutions; by ultraviolet rays or gamma rays. Microorganisms can also be removed mechanically by high-speed centrifugation or by filtration. In the world of health, sterilization is very important to do to provide a maximum therapeutic effect. Sterile means free from all microbes, both pathogens or not. This process involves the application or physical process with the aim of killing or eliminating microorganisms. Another term that is commonly known is disinfection, which is a process of killing or eliminating microorganisms that can cause disease.

Disinfecting agents are disinfectants, which are usually chemical and are used for non-living objects. Disinfection does not guarantee the object to be sterile because viable spores and some microorganisms can still be left.

b. Variabel Dependent( Variabel Dependent)

Table 6 Distribution of patient frequencies based on the incidence of plebitis in space

\begin{tabular}{lcc}
\hline \multicolumn{1}{c}{ Genesis Plebitis } & Frequency & $(\boldsymbol{\%})$ \\
\hline occur plebitis & 4 & 27 \\
Phlebitis does not occur & 11 & 73 \\
\hline Total & 15 & 100 \\
\hline Source: Primary Datar & &
\end{tabular}

Based on table 4.6 it can be seen that there are as many as 4 people (27\%) of plebitis, whereas there are 11 patients $(73 \%)$ of patients without plebitis and the incidence of plebitis is caused either by mechanical, chemical or infective factors. This is indicated by the presence of red inflammation in the tubes, pain and swelling in the puncture area or vein. Phlebitis occurs due to mechanical factors, namely the size of the 
infusion catheter, location of infusion installation, infusion fixation ${ }^{10}$, the same thing was also stated by INS that the incidence of plebitis was caused by infusion that was too long, and plebitis occurred due to the age factor as stated.

Researchers believe that the high infection of plebitis is caused by several factors/domains such as the size of the infusion catheter, location of infusion, fixation of infusion, age and length of infusion. Not from sex and medical diagnosis, because this is caused directly related to plebitis, namely intravenous therapy (infusion catheter size, location of infusion, fixation of infusion) and age, this is because age directly influences plebitis which is seen in terms of venous function patient.

Prevention of plebitis can be done in a way how the nurse can choose the right size for the patient's vein, the location of the installation is far from the area that is mostly carried out by the patient so as to minimize trauma to the intima tunica, given adequate fixation and fixation far from the location of the infusion near with joints that can make the plaster can be sagging due to excessive movement, then the age factor where nurses must be observant to do intravenous therapy, from choosing the size of the infusion catheter to infusion care because the elderly have decreased venous function, and the duration of infusion must be below $3 \times 24$ hours adjusted to the standards imposed by the INS.

The domains/factors that are distributed to the incidence of plebitis described by researchers are the installation of infusion, the size of the infusion catheter, infusion fixation, the age of the patient and the length of infusion.

\section{Bivariate Analysis}

Table 7 The Relation Between Sterility of the Device for Infusion and the Occurrence of Pebitis in Patients in the Flamboyant Room Abdul WahabSjahranie Hospital Samarinda

\begin{tabular}{|c|c|c|c|c|c|c|c|}
\hline \multirow{3}{*}{ The Sterility of equipment } & \multicolumn{4}{|c|}{ The incidence of plebitis } & \multicolumn{2}{|c|}{ Total } & \multirow[t]{3}{*}{ P-Value } \\
\hline & \multicolumn{2}{|c|}{ Plebitis occurs } & \multicolumn{2}{|c|}{$\begin{array}{c}\text { There is no } \\
\text { plebitis }\end{array}$} & \multirow[b]{2}{*}{ JS } & \multirow[b]{2}{*}{$\%$} & \\
\hline & $\mathbf{P}$ & $\%$ & $\mathbf{T P}$ & $\%$ & & & \\
\hline Sterile & 0 & $0,0 \%$ & 4 & $26,7 \%$ & 4 & $26,7 \%$ & 0,454 \\
\hline Not sterile & 4 & $26,7 \%$ & 7 & $46,7 \%$ & 11 & $73,3 \%$ & \\
\hline Total & 4 & 27 & 11 & 73 & 15 & 100 & \\
\hline
\end{tabular}

Source: Primary Data 2013

Based on table 4.7 above, it can be seen that according to SPO, there were 0 patients $(0.0 \%)$ plebitis, and according to SPO there were no 4 patients $(26.7 \%)$. while those who did not fit the SPO occurred plebitis as many as 4 patients $(26.7 \%)$ and not according to the SPO did not occur as much as plebitis as many as 7 patients (46.7\%).

Chi square statistical test results using Yate's correlation shows that the opportunity value (p) of 0.454 is more than the value of the significance level $(\alpha)$ of 0.05 , so Ho is rejected. This shows that there is no statistically significant relation between the sterility of the device with the incidence of plebitis in patients in the flamboyant room of Abdul WahabSjahranie Hospital Samarinda. This study uses a correlative descriptive research design that is a research method carried out to create a picture or description of a situation that is being or carried out objectively ${ }^{11}$, with a cross sectional approach. The 
cross sectional approach is a study conducted to describe the relation between independent variables and dependent variables, together in a certain period ${ }^{8}$. Data obtained from observation sheets given to nurses in the Flamboyan Room. Data were then analyzed for the relation between the sterility of the device at the time of infusion and the incidence of plebitis in patients in the Flamboyant Room of the Abdul Wahab Hospital, SjahranieSamarinda.

Based on table 4.7 above, it can be seen that according to SPO, there were 0 patients $(0.0 \%)$ plebitis, and according to SPO there were no 4 patients $(26.7 \%)$. While those who did not fit the SPO occurred plebitis in 4 patients $(26.7 \%)$ and not according to the SPO did not occur plebitis in 7 patients $(46.7 \%)$.

Chi square statistical test results using Yate's correlation shows that the opportunity value (p) of 0.454 is more than the value of the significance level $(\alpha)$ of 0.05 , so Ho is rejected. This shows that there is no statistically significant relation between the sterility of the device with the incidence of plebitis in patients in the flamboyant room of Abdul WahabSjahranie Hospital Samarinda, a consistent study conducted with the title of the relation between infusion installation with the incidence of plebitis in Prikasih Hospital South Jakarta results show that there is a relation between the location of the infusion (pvalue $=0.042$ ), the type of infusion given (value $=0.001$ ) and the infusion ( $p$-value $=$ 0.011 ), and this is also related to the presence of equipment sterility that is a process to kill all the microorganisms that exist in the equipments if it is grown in nature, there are no microorganisms that can multiply in the equipments. Sterilization must be able to kill microorganisms so that the equipmentss used are sterile and do not cause instability of the device.The growth of microorganisms shows that bacterial growth is still ongoing and the sterilization process is incomplete. If the sterilization is complete, the bacterial spores which are the most resistant form of microbial life will be destroyed. For microbiological purposes in an effort to obtain a sterile state, microorganisms can be killed locally by heat (heat), gases such as formaldehyde, ethylene oxide or betapriolactone by various chemical solutions; by ultra violet rays or gamma rays. Microorganisms can also be removed mechanically by high-speed centrifugation or by filtration. In the world of health, sterilization is very important to do to provide a maximum therapeutic effect. Sterile means free from all microbes, both pathogens or not. This process involves the application or physical process with the aim of killing or eliminating microorganisms. Another term that is commonly known is disinfection, which is a process of killing or eliminating microorganisms that can cause disease.

Between attitude and practice of nurses in the prevention of phlebitis and sterility of equipment is $r=0.05$, according to Guilford it means that there is no moderate relation because of the value of $r$ correlation $<0$, meaning that there is no linear negative relation. The sterility of the equipmentss the nurse's practice will get better. means there is no relation between the sterility of the device with the practice of nurses by preventing the occurrence of phlebitis in the inpatient ward.

Infections related to infusion can be reduced by four interventions: the nurse carries out an active hand washing technique to eliminate gram-negative organisms before wearing gloves when performing venous puncture procedures, replacing intravenous solutions at least every 24 hours, replacing all peripheral venous catheters at least - at least 72 hours, in addition to that the nurse must also explain to patients not to move 
much in the area that is attached to the infusion, turn off the infusion when to the bathroom.

According to a statement that the risk for phlebitis infection is greater in older people / elderly because older people will experience stiffness of blood vessels. This also makes it more difficult to install intravenous therapy/risk of venous infection can happen.

Researchers argue that people who are elderly/middle aged and adults do not have good venous function due to decreased physiological function so that the risk of venous injury caused by infusion catheters can occur and can cause phlebitis, this can also be due to the size of the catheter infusion, where if the size of the larger infusion catheter is used in patients who have decreased venous function, then there can be a risk of venous damage that can cause phlebitis.

So it can be concluded that the incidence of phlebitis which is an infection that occurs in an intravenous needle puncture wound due to many factors that influence it include: poor hand washing techniques during installation or infusion care, aseptic techniques that are not good at the time of pricking, and the possibility Another higher factor is the age/age factor.

Factors that cause phlebitis include the drug being entered In the injection, infusion flow velocity and catheter material used, infusion catheter size and location of the puncture are inappropriate.

Researchers argue from the conclusion of the above theory that this happens because the sterility of the device and the method of fitting the infusion in hand is the most dominant motion and has a value that is not much different, it can cause plebitis, at this location there is also a equipmentskaran used not sterile and can also occur because of the disease experienced or the patient's age.

The results of this study were conducted who stated the average incidence of plebitis was $\geq 24$ hours and $\leq 72$ hours after intravenous therapy. And the results of the study showed that the location of infusion was located in the cephalic vein and there was no plebitis of 11 respondents $(91.7 \%)$. While the location of infusion was located in the metacarpal vein and phlebitis occurred by 20 respondents $(41.7 \%)^{6}$.

Pebitis is an inflammatory reaction that occurs in veins characterized by pain, redness, swelling, heat, induration (hardening) in the puncture area, and hardening along the veins ${ }^{10}$.

Plebitis is caused either by mechanical, chemical, or infective factors. Divided the causes of plebitis into four categories, namely chemical pebitis, mechanical plebitis, bacterial plebitis, and post-infusion plebitis ${ }^{10}$. Mechanical plebitisoccurs because the size of the needle is too large so that it interferes with the flow of blood around it, and causes irritation to the walls of blood vessels. It is also caused by improper insertion location, such as if the catheter is placed in the area of flexion often causing mechanical plebitis ${ }^{12}$. 


\section{CONCLUSION}

Based on the results of research and discussion, the following conclusions are obtained the description of the characteristics of respondents in the flamboyant room of Abdul WahabSjahranie Hospital in Samarinda by sex is mostly female (86.6\%) and, by age most are <30 years (86.6) and, based on education most are D III (80\%) and S1 (20\%) and based on the length of work most of it is $<5$ years (66.6). The sterility of the infusion device shows that there are 4 sterile respondents $(26.7 \%)$ and those who are not sterile; there are 11 respondents $(73.3 \%)$. The incidence of plebitis seen that the majority of patients had plebitis as many as 4 people (27\%), while patients who did not have plebitis as many as 11 people (73\%).Chi square statistical test results using Yate's correlation shows that the opportunity value (p) of 0.454 is more than the significance level value $(\alpha)$ of 0.05 so that Ho is rejected. This shows that statistically there is no significant relation between the sterility of the nurses and the incidence of plebitis in patients in the flamboyant room of Abdul WahabSjahranie Hospital Samarinda.

\section{ACKNOWLEDGEMENT}

Based on the conclusions drawn in this study, some suggestions that can be conveyed are:

\section{For Nurses}

a. The results of this study are expected to be applied to nurses throughout the hospital room Abdul WahanSjahranieSamarinda especially the flamboyant room so that they can pay more attention to the sterility of nurses in putting up IVs.

b. Nurses are expected to prevent the occurrence of plebitis by paying more attention to things that can cause plebitis.

2. For related institutions, especially Abdul WahabSjahranie Hospital Samarinda

The flamboyant room of Abdul WahabSjahranie Hospital in Samarinda in preventing an increase in plebitis in order to pay more attention to the sterility of the device in installing the infusion.

\section{For Educational Institutions}

The results of this study are expected in educational institutions to add a reference source related to the incidence of plebitis.

4. For other researchers

This research uses the observation method and it is also hoped that the next researcher can use other variables and can also conduct research methods other than observation.

\section{REFERENCES}

1. Potter, Patricia A., \& Anne Griffin Perry,Buku Ajar Fundamental Keperawatan: Konsep, Proses, danPraktik, Edisi 4, Volume II, (2006)

2. Hindley, G, Infection control in peripheral cannulae nursing standard. Potter, P.A \& Perry, A.G. 2005. Buku Ajar Fundamental Keperawatan :Konsep, Proses, danPraktik. EGC, Jakarta, (2004). 
3. Andreas,Analisahubungankarakteristikperawatdantingkatkepatuhanperawatdalampelaksanaanprota ppemasanganinfus di RumahSakitBadrulAini Medan, Medan. Skripsi :Tidakdipublikasikan, (2009).

4. RohanidanHingawatiSetio,PanduanPraktikKeperawatanNosokomial. Yogyakarta : PT Citra Parama, (2010).

5. Darmawan, I,Plebitis, apapenyebabnyadanbagaimanacara mengatasinya?.http://www.otsuka.co.id/?content=article_detail\&id=68\&lang=id diunduhtanggal 5 Februari(2015).

6. Mulyani,TinjauanPelaksanaanStandarOperasionalProsedur (SOP) PemasanganInfusPadaPasien Di InstalasiGawatDarurat (IGD) RS PKU MuhammadiyahGombong. Skripsi :tidakdipublikasikan, 2011.

7. Pasaribu, Analisapelaksanaanpemasanganinfus di ruangrawatinapRumahSakit Haji Medan, (2008).

8. Hidayat, Alimul. Definisioperasional. Jakarta : EGC (2007).

9. Notoatmodjo, Soekidjo, Pendidikan Dan PerilakuKesehatan, Rineka, Cipta, Jakarta (2010).

10. Alexander, M., Corrigan, A., Gorski, L. Infusion Nursing : An Evidence, Based, Approach, Saunders, Elsevier. Inc. (2010).

11. Nursalam, ManajemenKeperawatan, AplikasidalamPraktekKeperawatanProfesional, SalembaMedika, Jakarta (2008).

12. Hankins, J., Lonsway, R.A.W Hendrick, C., \& Perdue, M.B. Infusion Therapy, Second Edition, WB Saunders Company (2001). 